\title{
Cytotoxic and antioxidant properties in vitro of Functional beverages based on blackberry (Rubus glaucus B.) and soursop
}

\section{(Annona muricata L.) pulps}

\author{
Alexandra Zambrano ${ }^{1}$, Rosa Raybaudi-Massilia ${ }^{1}$, Francisco Arvelo ${ }^{2,3}$ and Felipe Sojo ${ }^{2}$ \\ ${ }^{1}$ Facultad de Ciencias, Instituto de Ciencia y Tecnología de Alimentos, Universidad Central de \\ Venezuela, Postal code 1041-A, ZIP code 47097, Caracas, Venezuela; ${ }^{2}$ Fundación Instituto de \\ Estudios Avanzados, IDEA, Caracas, Venezuela; ${ }^{3}$ Facultad de Ciencias, Instituto de Biología \\ Experimental, Universidad Central de Venezuela, Caracas, Venezuela.
}

Corresponding Author: Alexandra Zambrano, Food Science and Technology MSc. ${ }^{1}$ Facultad de Ciencias, Instituto de Ciencia y Tecnología de Alimentos, Universidad Central de Venezuela, Postal code 1041-A, ZIP code 47097, Caracas, Venezuela.

Submission Date: July $30^{\text {th }}$, 2018, Acceptance Date: November $28^{\text {th }}$, 2018, Publication Date: November $30^{\text {th }}, 2018$

Citation: Zambrano A., Raybaudi-Massilia R., Arvelo F., Sojo F. Cytotoxic and antioxidant properties in vitro of Functional beverages based on blackberry (Rubus glaucus B.) and soursop (Annona muricata L.) pulps. Functional Foods in Health and Disease 2018; 8(11): 531-547. DOI: https://doi.org/10.31989/ffhd.v8i11.541

\begin{abstract}
Background: There are many kinds of tropical fruit available in Venezuela. Two of these fruits are the focus of our study: blackberry ("mora") and soursop ("guanábana"). These fruits have extraordinary bioactive components. For example, blackberry has antioxidant compounds such as anthocyanins, which are characteristic of the Rosaceae family. Acetogenins present in the Annonaceae family have been shown to possess cytotoxic properties that act against different types of tumor cells. In previous research, we have discovered how lyophilized soursop pulp has an elevated cytotoxic effect with an $\mathrm{IC}_{50}$ of $7.1940 \pm 1.06$ in human cervix carcinoma cells (HeLa) and $0.8460 \pm 1.29$ in human prostate carcinoma cells (PC3).
\end{abstract}

Objective: This study focused on the health benefits and properties of the soursop and blackberry. Our focus was to determine the antioxidant and cytotoxic properties in a formulated beverage containing blackberry, soursop, and yogurt containing probiotics and prebiotics.

Methods: The research includes the study of soursop pulp (SP), blackberry pulp (BP), and two formulations of the functional beverage selected through a sensorial analysis, F2 $(\mathrm{BP}+\mathrm{SP}+$ Yogurt + Truvía ${ }^{\circledR}+$ Sacarose $)$ and F3 $\left(B P+S P+\right.$ Yogurt + Truvía ${ }^{\circledR}+$ Sacarose + Sodium tripolyphosphate). Cell viability of prostate carcinoma cells (PC3), breast carcinoma without overexpression of the HER2/c-erb-2 gene (MCF-7), breast carcinoma in which the HER2/c-erb-2 gene is over-expressed $(\mathrm{SKBr} 3)$ and healthy cells of human connective tissue used as control 
(Fibroblasts). The previous indicated samples were assessed using MTT (3- (4,5-dimethylthiazol2-yl)-2,5-diphenyl-2H-tetrazolium bromide). The antioxidant activity of the functional beverage was also done using a fresh preparation of 1,1-diphenyl-2-picrylhydrazyl (DPPH).

Results: The BP demonstrated the highest cytotoxicity for both lines of breast cancer cell lines, MCF-7 and SKBR3. The values of the minimum concentration required to inhibit $50 \%$ of the cell population ( $\mathrm{IC}_{50}$ ) was $0.12 \pm 1.10$ and $1.81 \pm 1.68 \% \mathrm{v} / \mathrm{v}$ respectively, followed by SP in MCF-7 and PC3 with values of $1.40 \pm 1.03$ and $1.34 \pm 1.06$ respectively. At the same time, the effectiveness of the formulations used found that $3.60 \pm 1.04 \% \mathrm{v} / \mathrm{v}$ of F2 beverage was necessary to achieve $50 \%$ inhibition of cell viability of MCF-7 line. For the formulation F3, it was necessary to use a concentration of $5.21 \pm 1.04 \% \mathrm{v} / \mathrm{v}$ for that tumor cell line. However, the F2 and F3 formulations demonstrated $\mathrm{IC}_{50}$ values of $3.69 \pm 1.08 \% \mathrm{v} / \mathrm{v}$ and $2.50 \pm 1.08 \% \mathrm{v} / \mathrm{v}$ respectively for the PC3 cell line. On the other hand, the antioxidant capacity of BP and SP reached elevated values at 30 minutes of exposure to DPPH, obtaining a rate of $85.28 \pm 0.11$ and $80.94 \pm 0.07 \%$ respectively by using a concentration of $12.5 \%, \mathrm{~F} 2$ and $\mathrm{F} 3$ formulations also reached values of $83.97 \pm 0.46$ and $85.62 \pm 0.11 \%$ at $100 \%$ concentration of both drinks respectively.

Conclusion: We discovered that the cytotoxic activity of both formulations prepared, as well as the pulps were fairly good, revealing highly effective consequences for the inactivation of breast tumor cells MCF-7 and prostate tumor cells PC3. Moreover, BP and SP demonstrated a high antioxidant activity, with a synergistic effect accomplished by the mixture on F2 and F3.

Keywords: Functional beverage, cytotoxic, antioxidant, soursop, blackberry, yogurt.

\section{INTRODUCTION}

In recent times, fruits and vegetables have been promoted as healthy foods due to their demonstrated antioxidant and anticancer properties [1, 2, 3, 4]. Organizations such as the Food and Agriculture Organization of the United Nations (FAO), World Health Organization (WHO), World Cancer Research Fund, and Global Alliance for the Promotion of Fruit and Vegetable Consumption "5 a day" (AIAM5) have recommended the consumption of fruits and vegetables as a key component of a healthy diet for the prevention of chronic diseases [5]. In particular, FAO and WHO have promoted incomes for farmers by increasing the production and supply and the consumption of fruit and vegetables [6,7]. The Harvard University indicated that at least half of the meal should be based on fruits and vegetables in order to be considered a healthy meal. In the last decade, the demand for "healthy" foods and beverages has increased in many parts of the world $[9,10]$. From 1980, these type of "healthy" foods and beverages have been called "functional foods," a term which originated in Japan [11]. The demand has increased due to the prevalence of chronic diseases, busy lifestyles, low consumption of convenience foods, and insufficient exercise $[12,10]$.

In 1991, the Ministry of Health of Japan introduced rules for the approval of a specific healthrelated food category called FOSHU (Food for Specified Health Uses) which included the establishment of specific health claims for this type of food [11, 13, 14, 15, 16]. In 2015, the Functional Food Center defined functional food as a natural or processed food that contains known or unknown biologically-active compounds. Foods in a defined or adequate amount provide a 
clinically proven and documented health benefit for the prevention or treatment of chronic disease [17].

Fruits and vegetables are rich sources of many diverse nutrients and bioactive compounds, capable of modulating metabolic processes and resulting in the promotion of better health. They exhibit beneficial effects such as antioxidant activity, inhibition or induction of enzymes, inhibition of receptor activities, and induction and inhibition of gene expression [18]. A combination of fruits has been demonstrated to exhibit additive or synergistic effects on enhancing the antioxidant effectiveness and status in human subjects [19, 20, 21].

Edible berries like blackberries from the Rosaceae family, genus Rubus, are known for curing and preventing a wide variety of ailments, such as colitis, in folk medicine [22]. Apart from vitamins, minerals, sugars, and fibers they are rich in bioactive compounds including phenolics, flavonoids, and tannins. These phytochemicals have been reported to possess anticancer and antioxidant activities [23]. Studies have also indicated that the antioxidant effect of berries are directly associated with its anticancer potential [12, 13] and anti-inflammatory properties [25, 26]. Digested metabolites from wild blackberries ( $R$. brigantinus and $R$. vagabundus) in human plasma could protect neuronal cells against oxidative damage, which is an influential factor for neurodegeneration [27].

In vitro cell culture studies demonstrated how hull blackberry extract inhibited HT-29 colon tumor cell growth in a concentration-dependent manner with $49.2 \mu \mathrm{g}$ of total anthocyanins $/ \mathrm{mL}$ without cytotoxicity [28]. The content of the total polyphenols and total anthocyanins are significantly related to the antioxidant activity that can prevent diseases generated by the action of free radicals [29, 30, 31, 32, 33, 34]. Blackberries are rich in anthocyanins and flavonoid glycosides [35, 36]. These compounds provide natural pigmentation and exhibit a wide range of antioxidant protection and therapeutic benefits including the integrity of genomic DNA, potent cardioprotective, neuroprotective, anti-inflammatory, and anticarcinogenic properties [21, 37, 38, $39,19,40]$.

The fruit soursop (Annona muricata L.) which comes from the Annonaceae family (also called "guanábana" or "chirimoya"), has attributed various health claims, in addition to being a fruit used in products like jellies, yogurts, and cakes. Soursop pulp has high antioxidant potential, with a half-maximal inhibitory concentration $\left(\mathrm{IC}_{50}\right)$ of $2.0 \mathrm{mg} / \mathrm{mL}$ determined by the method of free radical 1,1-diphenyl - 2 picrylhydrazyl (DPPH), which has been linked to the high content of phenolic compounds (368 mg / $100 \mathrm{~g}$ ) [41, 42]. Another health and wellness property of soursop is their cytotoxic activity against various types of cancers; acetogenins of Annonaceaes have cytotoxic activity against several types of cancer cells such as prostate cancer (PC3), breast (MCF7), lung (A-549) [42]. Soursop pulp and seed also have higher cytotoxic activity on the PC3 (0.0024 to $1.275 \mu \mathrm{g} / \mathrm{mL})$ and HeLa $(0.0011$ to $7.194 \mu \mathrm{g} / \mathrm{mL})$ cell lines with low impact on healthy cells (fibroblasts, as control) [43].

In this way, it is possible to incorporate a large number of antioxidants and natural bioactive components in the human body through the consumption of blackberries and soursop. Many researchers report that functional foods represent one of the most interesting areas of research and innovation in the food field [44]. Thus, the aim of this study was to determine the antioxidant and cytotoxic properties of formulations of a beverage made from blackberry, soursop, and yogurt with 
probiotics and prebiotics incorporated in order to demonstrate its properties, welfare, and consumer health by including antioxidants, anti-cancer, and gastrointestinal properties to promote general health.

\section{MATERIALS AND METHODS \\ Fruit}

Annona muricata L. (soursop) and Rubus glaucus B. (blackberry) at commercial ripeness (stage of ripeness for consumption) were selected in a local supermarket (Caracas, Venezuela) and maintained at $7^{\circ} \mathrm{C}$ until processing.

\section{Preparation of functional beverage}

Different formulations were developed containing $40 \%$ of liquid yogurt prepared from a skim powdered milk reconstituted and homogenized at $17.0 \%$ with the addition of inulin $(3.0 \%)$, and then heat-treated $\left(95^{\circ} \mathrm{C}\right.$ x $10 \mathrm{~min}$.) before the incorporation of starter cultures (CHR HANSEN lactic culture with Bifidobacterium BB-12 $\left(\right.$ ) ) and kept at $41{ }^{\circ} \mathrm{C}$ until pH 4.3. The rest of the formulation $(60 \%)$ consisted of an elaborated mixture from pulps of soursop and blackberries combined with drinking water, Truvía ${ }^{\circledR}$ sweetener, and sucrose. Two formulations of the beverage ranging only in content of water, sweeteners, and in the addition of a stabilizing salt (sodium tripolyphosphate). Mixtures were previously evaluated and selected through sensory analysis including 80 consumers from 18 to 60 years old.

\section{Human Tumor Cell Lines}

Human tumor cell lines from MCF-7 (breast carcinoma, without over-expression of the HER2/cerb-2 gene), SKBr3 (breast carcinoma, in which the HER2/c-erb-2 gene is overexpressed), and PC3 (prostate carcinoma) were provided by Marie-France Poupon from Laboratory of Molecular Cytogenetic and Oncology of the Curie Institute (Paris, France). Human dermis fibroblasts, used as control cells, were obtained from Laboratory of Tissue Culture and Tumor Biology of Instituto de Biología Experimental (Caracas, Venezuela). All cell lines were used to determine the cytotoxic activity from the functional beverage. MCF-7, SKBr3, and fibroblasts were grown in Dulbecco's modified Eagle's medium (DMEM; Gibco, USA) supplemented with $10 \%$ (v/v) heat inactivated fetal bovine serum (FBS; Gibco), $2 \mathrm{mM}$ glutamax (Gibco), 100 units/mL penicillin (Gibco) and $100 \mu \mathrm{g} / \mathrm{mL}$ streptomycin (Gibco). PC3 was grown in Roswell Park Memorial Institute medium (RPMI 1640; Gibco) supplemented with 10\% (v/v) heat inactivated FBS, 2 mM glutamax (Gibco), 100 units $/ \mathrm{mL}$ penicillin (Gibco), and $100 \mu \mathrm{g} / \mathrm{mL}$ streptomycin (Gibco). For treatments, exponentially growing cells were collected, counted, re-suspended in fresh culture medium, and incubated in 96 sterile well plates.

\section{Cytotoxicity Test}

The evaluation of the cytotoxic activity was done with previous centrifugation $(5.000 \mathrm{rpm} \times 15$ min.) of the samples to obtain the water phase and then filtrated $(20 \mu \mathrm{m})$. Cell viability was assessed using the MTT (3- (4,5-dimethylthiazol-2-yl)-2,5-diphenyl-2H-tetrazolium bromide) test, which is based on the ability of viable cells to metabolically reduce a yellow tetrazolium salt (MTT; Sigma, USA) to purple crystals of formazan [45]. This reaction takes place when mitochondrial reductases are active. Cells were seeded in 96 -well plates $\left(5 \times 10^{5}\right.$ cells/well $)$ and incubated at $37^{\circ} \mathrm{C}$ 
for 72 hours with the samples (functional beverage and each of the fruit pulps selected) at concentrations of $0.00 ; 0.04 ; 0.20 ; 0.40 ; 0.80 ; 1.70 ; 2.70 ; 5.00 ; 7.50 ; 10.00 \% \mathrm{v} / \mathrm{v}$, diluted in bidistilled water respectively, in a humidified atmosphere with $5 \% \mathrm{CO}_{2}$. After incubation, the medium was removed, and the cells were treated with $100 \mu \mathrm{L}$ MTT for 3 hours at $37^{\circ} \mathrm{C}$. Subsequently, the MTT was removed and $100 \mu \mathrm{L}$ dimethyl sulfoxide (DMSO) was added. The formazan product was quantified with the help of a microplate reader TECAN-Sunrise ${ }^{\mathrm{TM}}$ at 570 nm (Tecan Group LTD, Männedorf, Switzerland). Taxol (Bristol-Myers Squibb, USA) was used as a positive control in the test. The experiment was carried out in triplicate.

\section{Selectivity Index for Cytotoxicity Test}

After the cytotoxicity test was calculated, the selectivity index (SI) as the $\mathrm{IC}_{50}$ (control cells)/IC $\mathrm{I}_{50}$ (tumor cell line) ratio was conducted. A selectivity index $>1$ indicates that the cytotoxicity on tumor cell lines surpassed that on the healthy non-tumor cells [46].

\section{Determination of Antioxidant Activity}

The antioxidant activity of the functional beverage was determined through the method described by Celep et al. 2012. The sample was centrifuged at $15.000 \mathrm{rpm} \times 15$ minutes to obtain the water phase, then were prepared in solutions of $3.15 ; 6.25 ; 12.50 ; 25.00 ; 50.00 ; 75.00 ; 100.00 \% \mathrm{v} / \mathrm{v}$, diluted in methanol, and those were mixed with $2.8 \mathrm{~mL}$ of freshly prepared $0.06 \mathrm{mM} 1$,1-diphenyl2-picrylhydrazyl (DPPH, Sigma-Aldrich, St. Louis, USA) solution in methanol. The mixture was shaken with a vortex and incubated in the dark at room temperature for 30 minutes. The absorbance was measured at $517 \mathrm{~nm}$ (the extract was added just after $30 \mathrm{~min}$ of dark incubation). Ascorbic acid $(176 \mu \mathrm{g} / \mathrm{mL})$ was used as reference substance (control). The absorbance was measured at 517 $\mathrm{nm}$. The antioxidant activity expressed as DPPH radical-scavenging activity was calculated as follows (Equation 1):

$$
\begin{aligned}
& \text { DPPH radical - scavenging activity (\%) } \\
& \qquad=\left(\frac{\text { Asorbance control }- \text { Absorbance sample }}{\text { Absorbance control }}\right)
\end{aligned}
$$

\section{Statistical Analysis}

The methods described before were repeated at least three times. The values of cytotoxicity, expressed in $\mathrm{IC}_{50}$, of formulated beverages were determined by a non-linear regression of individual experiments using the program GraphPad Prism v.5.02 (GraphPad Software, San Diego, CA, USA). To detect significant statistically differences ( $p$-values) analyses of variance (ANOVA) were carried out on both cytotoxic and antioxidant activity of the functional beverage; and between their concentrations using statistic package Statgraphics Centurion XVI (StatPoint Technologies). Multiple range tests, using the Fisher's LSD method, were then applied to determine which beverage and concentrations had significantly different $p$-values.

\section{RESULTS AND DISCUSSION Cytotoxic Activity}

Table 1, 2, 3, and 4 show the cytotoxic effect of the two formulated functional beverages ( $\mathrm{F} 2$ and F3) and pasteurized pulps, soursop (SP), and blackberry (BP) on human epidermal fibroblasts 
(control cells) and tumor cells (MCF-7, SKBr3 and PC3). A progressive decrease in cell viability was observed, depending on the product (F2, F3, SP and BP) and concentration, in a dosedependent manner. These results showed $p$-values differences between the percentages of viability; to compare between products and concentrations evaluated individually, fruit pulps evaluated were more unfavorable on the viability of the cells in relation to both beverages.

Thereby, through evaluating fibroblast cell viability (Table 1) it became clear using concentrations less than or equal to $5 \%$ of fruit pulp, viability remained close to $50 \%$, with values of $54.31 \pm 0.22 \%$ and $47.53 \pm 0.26 \%$ for the pulp of blackberry and soursop respectively, while viability at this concentration was kept at $100 \pm 1.90 \%$ when using the F2 formulation and 98.75 $\pm 0.34 \%$ by adding $\mathrm{F} 3$.

A greater effect was observed on human tumor cell lines. Specifically, breast cancer cell line MCF-7 viability percentages (Tables 2 ) were $43.52 \pm 0.32 \%$ and $59.31 \pm 1.85 \%$ for $5 \%$ of F2 and F3 drinks respectively. In contrast, for soursop and blackberry pulps viability was $36.25 \pm 0.19$ and only $9.10 \pm 0.61 \%$ respectively. Moreover, by using blackberry pulp in breast cancer cell line $\mathrm{SKBr} 3$ (Table 3), we found a greater cytotoxic effect on cell viability through a percentage viability of $8.35 \pm 0.36 \%$ at a concentration of $5 \%$ of the pulp. Followed by a $30.00 \pm 1.30 \%$ of viability for soursop pulp and $72.34 \pm 0.79 \%$ and $92.04 \pm 0.23 \%$ for F2 and F3 formulations respectively.

Table 4 has the results of the prostate cancer (PC3) cell line. Formulations F2 and F3 show a viability percentage of $44.38 \pm 0.29 \%$ and $56.05 \pm 0.68 \%$ at $5 \%$ concentration. We obtained a greater reduction using soursop and blackberry pulps, with values of $9.64 \pm 0.69 \%$ and $11.70 \pm$ $0.29 \%$ at the same concentration.

Table 1. Percentage of cell viability of fibroblast employing two functional beverages, F2 (Yogurt + Soursop and blackberry pulps + Sweeteners), F3 (Yogurt + Soursop and Blackberry pulps + Sweeteners + $\mathrm{pH}$ regulator), soursop and blackberry pulps (SP and $\mathrm{BP}$ ) in different concentrations.

\section{Celular Viability (\%)}

\begin{tabular}{|c|c|c|c|c|c|c|c|c|}
\hline$[\mathbf{P}]$ & F2 & & F3 & & SP & & BP & \\
\hline 0 & $100,00 \pm 1,00$ & $\mathrm{Aa}$ & $100,00 \pm 1,00$ & Aa & $100,00 \pm 1,00$ & $\mathrm{Ba}$ & $100,00 \pm 1,00$ & $\mathrm{Ba}$ \\
\hline 0,04 & $99,48 \pm 0,98$ & Аa & $100,00 \pm 0,12$ & Аа & $91,53 \pm 0,16$ & $\mathrm{Ba}$ & $100,00 \pm 0,91$ & $\mathrm{Ba}$ \\
\hline 0,2 & $98,06 \pm 0,74$ & Aab & $100,00 \pm 0,15$ & Aab & $77,67 \pm 0,11$ & Bab & $100,00 \pm 1,38$ & Bab \\
\hline 0,4 & $97,34 \pm 0,77$ & Aab & $97,59 \pm 0,60$ & Aab & $84,93 \pm 1,46$ & Bab & $100,00 \pm 1,14$ & Bab \\
\hline 0,8 & $96,44 \pm 0,72$ & Aab & $93,89 \pm 0,87$ & Aab & $83,77 \pm 1,30$ & Bab & $90,89 \pm 0,48$ & Bab \\
\hline 1,7 & $95,98 \pm 1,44$ & Aab & $100,00 \pm 0,12$ & Aab & $77,35 \pm 1,20$ & Bab & $82,82 \pm 0,50$ & Bab \\
\hline 2,7 & $100,00 \pm 0,69$ & Aab & $100,00 \pm 0,66$ & Aab & $64,72 \pm 0,33$ & Bab & $72,64 \pm 1,42$ & Bab \\
\hline 5 & $100,00 \pm 1,90$ & $\mathrm{Ab}$ & $98,75 \pm 0,34$ & $\mathrm{Ab}$ & $47,53 \pm 0,26$ & $\mathrm{Bb}$ & $54,31 \pm 0,22$ & $\mathrm{Bb}$ \\
\hline 7,5 & $94,24 \pm 1,42$ & Ac & $36,48 \pm 0,70$ & Ac & $22,39 \pm 0,22$ & $\mathrm{Bc}$ & $10,46 \pm 0,17$ & $\mathrm{Bc}$ \\
\hline 10 & $70,88 \pm 0,34$ & Ac & $26,10 \pm 0,15$ & Ac & $3,13 \pm 0,07$ & $\mathrm{Bc}$ & $3,31 \pm 0,35$ & $\mathrm{Bc}$ \\
\hline
\end{tabular}

$[P]:$ concentration of each product $(\%$ v/v), F2: Yogurt + Soursop and blackberry pulps + Sweeteners, F3: Yogurt + Soursop and blackberry pulps + Sweeteners + pH regulator, SP: soursop pulp, BP: blackberry pulp. Different capital letters (A y B) represent significant difference $p$-values between products (F2, F3, PM and PG). Different lowercase letters $(a, b, c)$ in the same column indicate significant differences ( $p$-values) between products concentration $(0,04$; $0,20 ; 0,40 ; 0,80 ; 1,70 ; 2,70 ; 5,00 ; 7,50$ y $10,00 \%)$. Values are mean of eight (8) determinations \pm standard deviation. 
Table 2. Percentage of cell viability of MCF-7 (breast carcinoma, without over-expression of the HER2/c-erb-2 gene) employing two functional beverage, F2 (Yogurt + Soursop and blackberry pulps + Sweeteners), F3 (Yogurt + Soursop and Blackberry pulps + Sweeteners + pH regulator), soursop and blackberry pulps (SP and BP) in different concentrations.

\begin{tabular}{crlrlrlll}
\hline & \multicolumn{7}{c}{ Celular viability (\%) } \\
\cline { 2 - 9 }$[\mathbf{P}]$ & \multicolumn{1}{c}{ F2 } & \multicolumn{10}{c}{ F3 } & \multicolumn{1}{c}{ SP } & \multicolumn{1}{c}{ BP } & \\
\hline 0 & $100,00 \pm 1,00$ & Aba & $100,00 \pm 1,00$ & Aa & $100,00 \pm 1,00$ & Ba & $100,00 \pm 1,00$ & Ca \\
0,04 & $97,82 \pm 0,27$ & Abab & $100,00 \pm 0,42$ & Aab & $87,55 \pm 0,78$ & Bab & $55,55 \pm 0,81$ & Cab \\
0,2 & $85,96 \pm 0,22$ & ABbc & $98,45 \pm 0,68$ & Abc & $77,93 \pm 0,83$ & Bbc & $51,22 \pm 0,76$ & Cbc \\
0,4 & $70,66 \pm 0,33$ & ABcd & $88,60 \pm 0,92$ & Acd & $63,27 \pm 0,46$ & Bcd & $40,77 \pm 0,87$ & Ccd \\
0,8 & $70,05 \pm 0,20$ & ABde & $87,62 \pm 0,74$ & Ade & $51,28 \pm 0,53$ & Bde & $28,28 \pm 0,81$ & Cde \\
1,7 & $58,06 \pm 0,34$ & ABdef & $84,05 \pm 0,79$ & Adef & $47,80 \pm 0,20$ & Bdef & $17,98 \pm 0,70$ & Cdef \\
2,7 & $56,86 \pm 0,16$ & ABef & $79,13 \pm 0,64$ & Aef & $43,21 \pm 0,59$ & Bef & $11,92 \pm 0,19$ & Cef \\
5 & $43,52 \pm 0,32$ & ABfg & $59,31 \pm 1,85$ & Afg & $36,25 \pm 0,19$ & Bfg & $9,10 \pm 0,61$ & Cfg \\
7,5 & $40,41 \pm 0,25$ & ABgh & $36,64 \pm 1,0$ & Agh & $23,44 \pm 0,27$ & Bgh & $1,76 \pm 0,32$ & Cgh \\
10 & $38,33 \pm 0,35$ & ABh & $0,00 \pm 0,73$ & Ah & $26,32 \pm 0,46$ & Bh & $1,76 \pm 0,18$ & Ch \\
\hline
\end{tabular}

$[P]$ : concentration of each product $(\%$ v/v), F2: Yogurt + Soursop and blackberry pulps + Sweeteners, F3: Yogurt + Soursop and blackberry pulps + Sweeteners + pH regulator, SP: soursop pulp, BP: blackberry pulp. Different capital letters (A, B, C) represent significant difference $p$-values between products (F2, F3, PM and PG). Different lowercase letters ( $a, b, c, d, e, f, g$ and $h)$ in the same column indicate significant differences ( $p$-values) between products concentration $(0,04 ; 0,20 ; 0,40 ; 0,80 ; 1,70 ; 2,70 ; 5,00 ; 7,50$ y 10,00 \%). Values are mean of eight (8) determinations \pm standard deviation

Table 3. Percentage of cell viability of SKBr3 (breast carcinoma, in which the HER2/c-erb-2 gene is over-expressed) employing two functional beverages, F2 (Yogurt + Soursop and blackberry pulps + Sweeteners), F3 (Yogurt + Soursop and Blackberry pulps + Sweeteners + pH regulator), soursop and blackberry pulps (SP and BP) in different concentrations.

\begin{tabular}{crlrlrlrl}
\hline & \multicolumn{7}{c}{ Celular viability (\%) } \\
\cline { 2 - 9 }$[\mathbf{P}]$ & \multicolumn{1}{c}{ F2 } & \multicolumn{1}{c}{ F3 } & \multicolumn{1}{c}{ SP } & \multicolumn{1}{c}{ BP } \\
\hline 0,00 & $100,00 \pm 1,00$ & Aa & $100,00 \pm 1,00$ & Aa & $100,00 \pm 1,00$ & Ba & $100,00 \pm 1,00$ & Ca \\
0,04 & $97,42 \pm 0,58$ & Aab & $100,00 \pm 0,61$ & Aab & $94,03 \pm 0,54$ & Bab & $82,17 \pm 0,50$ & Cab \\
0,20 & $96,67 \pm 0,24$ & Aabc & $100,00 \pm 0,84$ & Aabc & $93,8 \pm 0,22$ & Babc & $59,02 \pm 0,94$ & Cabc \\
0,40 & $94,09 \pm 0,66$ & Aabcd & $100,00 \pm 0,23$ & Aabcd & $88,64 \pm 0,89$ & Babcd & $52,05 \pm 1,88$ & Cabcd \\
0,80 & $93,77 \pm 0,29$ & Abcd & $100,00 \pm 1,77$ & Abcd & $84,22 \pm 0,77$ & Bbcd & $43,26 \pm 0,40$ & Cbcd \\
1,70 & $91,72 \pm 0,41$ & Acd & $100,00 \pm 0,00$ & Acd & $65,47 \pm 1,80$ & Bcd & $31,07 \pm 0,69$ & Ccd \\
2,70 & $89,82 \pm 0,28$ & Ade & $97,20 \pm 1,29$ & Ade & $57,72 \pm 0,74$ & Bde & $19,74 \pm 1,35$ & Cde \\
5,00 & $72,34 \pm 0,79$ & Ae & $92,04 \pm 0,23$ & Ae & $30,00 \pm 1,30$ & Be & $8,35 \pm 0,36$ & Ce \\
7,50 & $47,02 \pm 0,89$ & Af & $33,55 \pm 0,87$ & Af & $12,27 \pm 0,45$ & Bf & $7,5 \pm 0,23$ & Cf \\
10,00 & $29,18 \pm 0,58$ & Af & $30,06 \pm 1,56$ & Af & $4,34 \pm 0,71$ & Bf & $2,12 \pm 0,18$ & Cf \\
\hline
\end{tabular}

$[P]:$ concentration of each product $(\%$ v/v), F2: Yogurt + Soursop and blackberry pulps + Sweeteners, F3: Yogurt + Soursop and blackberry pulps + Sweeteners + pH regulator, SP: soursop pulp, BP: blackberry pulp. Different capital letters (A, B, C) represent significant difference $p$-values between products (F2, F3, PM and PG). Different lowercase letters ( $a, b, c, d$, e and f) in the same column indicate significant differences (p-values) between products concentration $(0,04 ; 0,20 ; 0,40 ; 0,80 ; 1,70 ; 2,70 ; 5,00 ; 7,50 \mathrm{y}$ $10,00 \%)$. Values are mean of eight (8) determinations \pm standard deviation. 
Table 4. Percentage of cell viability of PC3 (human prostate carcinoma) employing two functional beverages, F2 (Yogurt + Soursop and blackberry pulps + Sweeteners), F3 (Yogurt + Soursop and Blackberry pulps + Sweeteners $+\mathrm{pH}$ regulator), soursop and blackberry pulps (SP and BP) in different concentrations.

\begin{tabular}{|c|c|c|c|c|c|c|c|c|}
\hline \multirow[b]{2}{*}[\mathbf{P}]{} & \multicolumn{8}{|c|}{ Viabilidad celular $(\%)$} \\
\hline & $\mathbf{F} 2$ & & $\mathbf{F 3}$ & & PG & & PM & \\
\hline 0 & $100,00 \pm 1,00$ & Aa & $100,00 \pm 1,00$ & Aa & $100,00 \pm 1,00$ & $\mathrm{Ba}$ & $100,00 \pm 1,00$ & $\mathrm{Ba}$ \\
\hline 0,04 & $90,67 \pm 0,94$ & $\mathrm{Ab}$ & $81,08 \pm 0,19$ & $\mathrm{Ab}$ & $86,15 \pm 7,19$ & $\mathrm{Bb}$ & $83,83 \pm 0,68$ & $\mathrm{Bb}$ \\
\hline 0,2 & $86,03 \pm 0,77$ & $\mathrm{Ab}$ & $78,62 \pm 0,82$ & $\mathrm{Ab}$ & $83,92 \pm 0,45$ & $\mathrm{Bb}$ & $78,82 \pm 0,17$ & $\mathrm{Bb}$ \\
\hline 0,4 & $78,05 \pm 0,65$ & $\mathrm{Abc}$ & $75,25 \pm 0,40$ & $\mathrm{Abc}$ & $80,17 \pm 0,69$ & $\mathrm{Bbc}$ & $72,22 \pm 0,34$ & $\mathrm{Bbc}$ \\
\hline 0,8 & $75,19 \pm 0,11$ & Acd & $73,03 \pm 0,65$ & Acd & $61,19 \pm 1,38$ & Bcd & $63,15 \pm 0,68$ & Bcd \\
\hline 1,7 & $69,4 \pm 0,44$ & Ade & $67,09 \pm 0,22$ & Ade & $49,82 \pm 0,45$ & Bde & $57,87 \pm 0,49$ & Bde \\
\hline 2,7 & $65,54 \pm 0,16$ & $\mathrm{Ae}$ & $58,83 \pm 0,58$ & $\mathrm{Ae}$ & $44,55 \pm 1,91$ & $\mathrm{Be}$ & $44,43 \pm 0,74$ & $\mathrm{Be}$ \\
\hline 5 & $56,05 \pm 0,68$ & Af & $44,38 \pm 0,29$ & Af & $9,64 \pm 0,69$ & Bf & $11,7 \pm 0,29$ & $\mathrm{Bf}$ \\
\hline 7,5 & $38,52 \pm 0,52$ & Ag & $20,48 \pm 0,55$ & $\mathrm{Ag}$ & $0,00 \pm 0,86$ & $\mathrm{Bg}$ & $3,71 \pm 0,22$ & Bg \\
\hline 10 & $8,04 \pm 0,24$ & $\mathrm{Ag}$ & $10,90 \pm 0,41$ & $\mathrm{Ag}$ & $0,00 \pm 0,69$ & $\mathrm{Bg}$ & $0,85 \pm 0,10$ & Bg \\
\hline
\end{tabular}

$[P]:$ concentration of each product $(\%$ v/v), F2: Yogurt + Soursop and blackberry pulps + Sweeteners, F3: Yogurt + Soursop and blackberry pulps + Sweeteners + pH regulator, SP: soursop pulp, BP: blackberry pulp. Different capital letters (A and B) represent significant difference $p$-values between products (F2, F3, PM and PG). Different lowercase letters $(a, b, c, d, e . f$ and $g)$ in the same column indicate significant differences ( $p$-values) between products concentration $(0,04 ; 0,20 ; 0,40 ; 0,80 ; 1,70 ; 2,70 ; 5,00 ; 7,50$ y 10,00 \%). Values are mean of eight (8) determinations \pm standard deviation.

In Table 5, the minimum concentration required to inhibit 50\% of the cell population $\left(\mathrm{IC}_{50}\right)$ in each cancer cell line is shown. Blackberry pulp showed the highest cytotoxicity for both lines of breast cancer, MCF-7 and SKBR3, with values of $0.12 \pm 1.10 \%$ and $1.81 \pm 1.68 \% \mathrm{v} / \mathrm{v}$ respectively, followed by soursop pulp in MCF-7 and PC 3 with values of $1.40 \pm 1.03 \%$ and 1.34 $\pm 1.06 \%$ respectively. While the beverages used were effective, a higher concentration of the formula F2 $(3.60 \pm 1.04 \% \mathrm{v} / \mathrm{v})$ was necessary to achieve $50 \%$ inhibition of cell viability of MCF7 line. In contrast, for the formulation F3, it was necessary to use a concentration of $5.21 \pm 1.04 \%$ $\mathrm{v} / \mathrm{v}$ for that cancer cell line. Surprisingly, the F2 and F3 formulations demonstrated $\mathrm{IC}_{50}$ values of $3.69 \pm 1.08 \% \mathrm{v} / \mathrm{v}$ and $2.50 \pm 1.08 \% \mathrm{v} / \mathrm{v}$ respectively for the PC3 cell line. 
Table 5. Cytotoxic activity expressed in $\mathrm{IC}_{50}$ values of formulated beverages (F2 and F3), soursop and blackberry pulps (SP and BP) on various human tumor cell lines.

\begin{tabular}{rcccc}
\hline & \multicolumn{4}{c}{ Values of IC50 $(\% \mathbf{~ v / v}) *$} \\
\cline { 2 - 5 } Product & Fibroblasts & MCF-7 & SKBr3 & PC3 \\
\hline F2 & $11,43 \pm 1,01$ & $3,60 \pm 1,04$ & $7,92 \pm 1,04$ & $3,69 \pm 1,08$ \\
F3 & $7,30 \pm 1,01$ & $5,21 \pm 1,04$ & $5,93 \pm 1,00$ & $2,50 \pm 1,08$ \\
SP & $3,54 \pm 1,05$ & $1,40 \pm 1,03$ & $5,16 \pm 1,08$ & $1,34 \pm 1,06$ \\
BP & $4,22 \pm 1,02$ & $0,12 \pm 1,10$ & $1,81 \pm 1,68$ & $1,33 \pm 1,07$ \\
\hline
\end{tabular}

*Values are mean of eight (8) determinations \pm standard deviation. IC $C_{50}:$ inhibitory concentration 50; F2: Yogurt + Soursop and blackberry pulps + Sweeteners, F3: Yogurt + Soursop and blackberry pulps + Sweeteners $+p H$ regulator, SP: soursop pulp, BP: blackberry pulp; Fibroblasts (healthy cells of animal connective tissue, used as control) MCF-7 (breast carcinoma, without over-expression of the HER2/c-erb-2 gene); SKBr3 (breast carcinoma, in which the HER2/c-erb-2 gene is over-expressed); PC3 (human prostate carcinoma).

In contrast to the effectiveness observed in MCF-7 by $\mathrm{F} 2$ and $\mathrm{F} 3$ formulations, a greater $\mathrm{IC}_{50}$ in $\mathrm{SKBr} 3$ cell line was determined, reporting a value of $5.93 \pm 1.00 \% \mathrm{v} / \mathrm{v}$ for $\mathrm{F} 3$ and $7.92 \pm 1.04 \%$ $\mathrm{v} / \mathrm{v}$ for F2, compared with $5.21 \pm 1.04$ and $3.60 \pm 1.04$ obtained for MCF-7. Compared to the trend observed in both cell lines MCF-7 and SKBr3 where blackberry pulp was more effective in inhibiting the growth of these cells, the results obtained in cell lines PC3 yielded $\mathrm{IC}_{50}$ values like; $1.34 \pm 1.06$ and $1.33 \pm 1.07$ for blackberry pulp and soursop pulp respectively, followed by the results obtained in the F2 and F3 formulations, $3.69 \pm 1.08 \%$ and $2.50 \pm 1.08 \% \mathrm{v} / \mathrm{v}$.

By calculating the selectivity index (SI) [48] for each tumor line with each product studied, cancer cell lines were more affected compared to the control cells, with SI values greater than 1 (see Table 6). The largest SI was found in fruit pulps to MCF-7 cells, with a value of 35.17, being about 35 times more effective for the MCF-7 line compared to control cells, followed by the F2 formulation with a SI value of 3.18. The difference between both beverages in MCF-7 cells may be due to a $\mathrm{pH}$ which was adjusted in the $\mathrm{F} 3$ formulation with sodium tripolyphosphate, resulting in a pH 4.09 unlike $\mathrm{pH} 3.80$ in F2. Meanwhile, the F2 and F3 formulations showed very similar values on SKBR3 and PC3 lines, 1.44 and 1.23 and 3.08 and 2.92 respectively.

Table 6. Determination of selectivity index (SI) in the functional beverages (F2 and F3) and pasteurized pulps from soursop (SP) and blackberry (BP) in different cell lines.

\begin{tabular}{cccc}
\hline & \multicolumn{3}{c}{ SI } \\
\cline { 2 - 4 } Product & MCF-7 & SKBr3 & PC3 \\
\hline F2 & 3,18 & 1,44 & 3,08 \\
F3 & 1,40 & 1,23 & 2,92 \\
SP & 2,53 & 0,68 & 2,64 \\
BP & 35,17 & 2,33 & 3,17
\end{tabular}

*Values are mean of eight (8) determinations \pm standard deviation. SI: Selectivity index; F2: Yogurt + Soursop and blackberry pulps + Sweeteners, F3: Yogurt + Soursop and blackberry pulps + Sweeteners + pH regulator, SP: soursop pulp, BP: blackberry pulp; Fibroblasts (healthy cells of animal connective tissue, used as control) MCF-7 (breast carcinoma, without over-expression of the HER2/c-erb-2 gene); SKBr3 (breast carcinoma, in which the HER2/c-erb-2 gene is over-expressed); PC3 (human prostate carcinoma). 
Studies by Raybaudi-Massilia et al. demonstrated that the use of soursop seed extracts by maceration and lyophilization techniques applied individually in breast cancer cell lines MCF-7 reached $\mathrm{IC}_{50}$ values of $70.15 \pm 1.02$ and $27.09 \pm 1.03 \mathrm{mg} / \mathrm{mL}$ respectively. Moreover, the extraction by maceration of seeds also demonstrated cytotoxicity with an $\mathrm{IC}_{50}$ value of $20.50 \pm$ $1.01 \mathrm{mg} / \mathrm{mL}$ in cell cultures SKBr3 [43]. In contrast, studies using lyophilized soursop pulp are only effective in inhibiting the growth of PC3 cells with an $\mathrm{IC}_{50}$ value of $0.846 \pm 1.29 \mathrm{mg} / \mathrm{mL}$.

Numerous studies have shown that acetogenins from Annonaceas are responsible for their cytotoxic activity, suggesting their potential use as an antitumor agent $[49,50,51]$. The mode of action of acetogenins is through inhibition of nicotinamide adenine dinucleotide-ubiquinone oxidoreductase (complex I) in mitochondria, in conjunction with suppressive inhibiting the adenosine triphosphate (ATP) production, especially in cancer cells with a high metabolic rate generating apoptosis [52, 53]. Additionally, Chiu et al. indicated that acetogenins of Annonaceaes as bullatacin induce apoptosis through reducing intracellular cyclic guanosine monophosphate (cGMP) and cyclic adenosine monophosphate (cAMP) values in human hepatoma cells 152.2 [53].

Among different medicinal uses attributed to blackberry, its anticarcinogenic, antiviral and antiallergic effects have currently been examined. Studies by Bowen-Forbesa et al. in which they employed a hexane extract of Rubus Jamaican species, determined the great potential to inhibit the growth of colon cancer cells, breast, lung, and gastric. Moreover, they discovered that hexane extracts were more effective than those made in methanol or ethyl acetate, suggesting that nonpolar components, such as fats and / or terpenes extracted from seeds of berries may be an effective anticancer agent. Likewise, the high content of anthocyanins of this fruit suggest that its consumption could generate health benefits useful in the production of functional foods [54]. Ross et al. at the James Hutton Institute suggests that ellagitanins of blackberries are particularly effective against cervical cancer cells (HeLa) "in vitro," followed by blackberry extracts rich in anthocyanins, with an $\mathrm{IC}_{50}$ of $0.013 \mathrm{mg} / \mathrm{mL}$ and $0.067 \mathrm{mg} / \mathrm{mL}$ respectively [55].

\section{Antioxidant Activity}

Through the quantification of the absorbance decrease of the oxidant radical 1,1-difenil-2-picrilhidrazilo (DPPH) determined at $517 \mathrm{~nm}$ at 0 and $30 \mathrm{~min}$, we obtained the antioxidant activity of the formulated beverages, F2 (Blackberry + Soursop + Yogurt + Truvía ${ }^{\circledR}+$ Sacarose) and F3 (Blackbery + Soursop + Yogurt + Truvía ${ }^{\circledR}+$ Sacarose + Sodium tripolyphosphate), and of the pasteurized fruit pulps, blackberry (BP), and soursop (SP). A higher antioxidant activity was expressed for both functional beverages, $\mathrm{F} 2$ and $\mathrm{F} 3$, without statistically significant differences ( $p$ values) among them (Table 3 ), as well as differences between exposure times ( 0 or $30 \mathrm{~min}$ ).

In this way, $p$-values for each beverage antioxidant activity were discovered, but when comparing the exposure times to the reagent with a value of $30.35 \pm 0.66 \%$ at time zero and 83.97 $\pm 0.46 \%$ after thirty minutes exposure in $\mathrm{F} 2$ and $47.81 \pm 0.11 \%$ and $85.62 \pm 0.11 \%$ respectively for F3. Moreover, statistically significant differences for different concentrations of the formulations employed were also established, resulting in a direct proportional relationship, where the higher concentration of the product reached greater antioxidant capacity, from values of 14.98 
\pm 0.15 and $24.57 \pm 0.24 \%$ after 30 minutes of exposure using a $3.15 \%$ of the F2 and F3 formulations to values of $83.97 \pm 0.46 \%$ and $85.62 \pm 0.11 \%$ at $100 \%$ of both drinks respectively. The results obtained for the antioxidant capacity of blackberry and soursop pulp (Table 7) also reached elevated values at 30 minutes of exposure to DPPH, obtaining a rate of $85.28 \pm 0.11 \%$ and $80.94 \pm 0.07 \%$ respectively by using a concentration of $12.5 \%$, values that are significantly higher than those obtained by using the F2 and F3 formulations. These differences are due to the proportions of blackberry and soursop pulp used in the formulated beverages.

Statistically significant differences were also determined by using different concentrations of each pulp, being in the case of blackberry pulp some interference of red-blue pigments, anthocyanins, which increased the absorbance reading. More importantly, this is a colorimetric method where the reduction of DPPH radical occurs from deep purple color, that in the presence of antioxidants pattern solutions such as vitamin $\mathrm{C}$ turns into a yellow color. Phenolic compounds have been attributed as antioxidants in soursop pulp by different authors [57, 41]. Previous studies with extracts of soursop by Raybaudi-Massilia et al. demonstrated that the antioxidant activity of a lyophilized soursop pulp, reached values of $68.53 \pm 0.20 \%$ at time 0 and $69.77 \pm 0.92 \%$ after 30 minutes of exposure to DPPH [43]. However, we had much better results in this study (88.68 \pm $0.11 \%$ and $88.75 \pm 0.07 \%$ respectively). This may be due to the type of processing subjected to the pulp, being in this research pasteurization, unlike a process of extraction and lyophilization in the case of the other study, which involved an initial extraction by cooking, followed by freezing and subsequent sublimation for obtaining lyophilized.

Table 7. Antioxidant activity expressed as DPPH radical-scavenging activity of formulated beverages (F2 and F3), soursop and blackberry pulps (SP and BP).

\begin{tabular}{|c|c|c|c|c|c|c|c|c|}
\hline \multirow{3}{*}{$\begin{array}{l}{[\mathrm{P}]} \\
(\% \\
\mathbf{v} / \mathbf{v})\end{array}$} & \multicolumn{8}{|c|}{ DPPH radical-scavenging activity $(\% ; \mathrm{v} / \mathrm{v})$} \\
\hline & \multicolumn{2}{|c|}{ F2 } & \multicolumn{2}{|c|}{ F3 } & \multicolumn{2}{|c|}{$\mathbf{B P}$} & \multicolumn{2}{|c|}{ SP } \\
\hline & 0 min. & 30 min. & 0 min. & 30 min. & 0 min. & 30 min. & 0 min. & 30 min. \\
\hline 100,00 & $\begin{array}{l}30,35 \pm \\
0,66^{\alpha \mathrm{Aa}}\end{array}$ & $\begin{array}{c}83,97 \pm \\
0,46^{\mathrm{aBa}}\end{array}$ & $\begin{array}{c}47,81 \pm \\
0,11^{\alpha \mathrm{Aa}}\end{array}$ & $\begin{array}{c}85,62 \pm \\
0,11^{\alpha \mathrm{Ba}}\end{array}$ & $\begin{array}{l}68,04 \pm \\
0,36^{\beta \mathrm{Aa}}\end{array}$ & $\begin{array}{c}68,55 \pm \\
0,58^{\beta \mathrm{Ba}}\end{array}$ & $\begin{array}{c}88,68 \pm \\
0,11^{\beta \mathrm{Aa}}\end{array}$ & $\begin{array}{c}88,75 \pm \\
0,07^{\mathrm{Baa}}\end{array}$ \\
\hline 75,00 & $\begin{array}{l}23,82 \pm \\
0,89^{\alpha \mathrm{Aab}}\end{array}$ & $\begin{array}{l}77,09 \pm \\
0,45^{\alpha \mathrm{Bab}}\end{array}$ & $\begin{array}{l}42,98 \pm \\
0,33^{\alpha \mathrm{Aab}}\end{array}$ & $\begin{array}{l}80,87 \pm \\
0,30^{\alpha \mathrm{Bab}}\end{array}$ & $\begin{array}{l}68,94 \pm \\
0,24^{\text {ßAab }}\end{array}$ & $\begin{array}{l}69,28 \pm \\
0,26^{\beta \mathrm{Bab}}\end{array}$ & $\begin{array}{l}87,25 \pm \\
0,13^{\beta \text { Aab }}\end{array}$ & $\begin{array}{l}88,53 \pm \\
0,07^{\beta \mathrm{Bab}}\end{array}$ \\
\hline 50,00 & $\begin{array}{c}19,35 \pm \\
0,75^{\alpha \mathrm{Aabc}}\end{array}$ & $\begin{array}{c}60,80 \pm \\
0,40^{\alpha \mathrm{Babc}}\end{array}$ & $\begin{array}{c}35,96 \pm \\
0,57^{\alpha \mathrm{Aabc}}\end{array}$ & $\begin{array}{c}64,15 \pm \\
0,26^{\alpha \mathrm{Babc}}\end{array}$ & $\begin{array}{l}76,26 \pm \\
0,26^{\beta \text { Aabc }}\end{array}$ & $\begin{array}{c}76,45 \pm \\
0,11^{\beta \mathrm{Babc}}\end{array}$ & $\begin{array}{c}68,04 \pm \\
0,26^{\beta A a b c}\end{array}$ & $\begin{array}{c}81,89 \pm \\
0,11^{\beta \mathrm{B} a b c}\end{array}$ \\
\hline 25,00 & $\begin{array}{c}18,09 \\
\pm 0,78^{\text {aAbcd }}\end{array}$ & $\begin{array}{c}38,04 \pm \\
0,40^{\alpha \mathrm{Bbcd}}\end{array}$ & $\begin{array}{c}31,55 \pm \\
0,40^{\alpha \mathrm{Abcd}}\end{array}$ & $\begin{array}{c}44,83 \pm \\
0,33^{\alpha \mathrm{Bbcd}}\end{array}$ & $\begin{array}{l}80,53 \pm \\
0,11^{\beta A b c d}\end{array}$ & $\begin{array}{c}80,68 \pm \\
0,07^{\beta B b c d}\end{array}$ & $\begin{array}{c}62,30 \pm \\
0,30^{\beta A b c d}\end{array}$ & $\begin{array}{c}81,43 \pm \\
0,11^{\beta \mathrm{Bbcd}}\end{array}$ \\
\hline 12,50 & $\begin{array}{c}16,28 \pm \\
0,89^{\alpha \text { Acde }}\end{array}$ & $\begin{array}{c}20,25 \pm \\
0,15^{\alpha \mathrm{Bcde}}\end{array}$ & $\begin{array}{c}24,64 \pm \\
0,57^{\alpha \text { Acde }}\end{array}$ & $\begin{array}{c}35,85 \pm \\
0,17^{\alpha B \text { Bde }}\end{array}$ & $\begin{array}{l}84,60 \pm \\
0,30^{\beta A c d e}\end{array}$ & $\begin{array}{c}85,28 \pm \\
0,11^{\beta B c d e}\end{array}$ & $\begin{array}{c}52,75 \pm \\
0,24^{\beta A c d e}\end{array}$ & $\begin{array}{c}80,94 \pm \\
0,07^{\beta B c d e}\end{array}$ \\
\hline 6,25 & $\begin{array}{l}13,92 \pm \\
0,40^{\alpha \text { Ade }}\end{array}$ & $\begin{array}{c}15,18 \pm \\
0,23^{\alpha \text { Bde }}\end{array}$ & $\begin{array}{l}20,38 \pm \\
0,47^{\alpha \text { Ade }}\end{array}$ & $\begin{array}{l}28,38 \pm \\
0,28^{\alpha \mathrm{Bde}}\end{array}$ & $\begin{array}{l}84,19 \pm \\
0,17^{\beta \text { Ade }}\end{array}$ & $\begin{array}{l}86,75 \pm \\
0,23^{\text {Bde }}\end{array}$ & $\begin{array}{l}40,19 \pm \\
0,07^{\beta \text { Ade }}\end{array}$ & $\begin{array}{c}60,94 \pm \\
0,11^{\beta \text { Bde }}\end{array}$ \\
\hline 3,15 & $\begin{array}{l}13,07 \pm \\
0,68^{\alpha \mathrm{Ae}}\end{array}$ & $\begin{array}{l}14,98 \pm \\
0,15^{\alpha \mathrm{Be}}\end{array}$ & $\begin{array}{l}16,04 \pm \\
0,43^{\alpha \mathrm{Ae}}\end{array}$ & $\begin{array}{c}24,57 \pm \\
0,24^{\alpha \mathrm{Be}}\end{array}$ & $\begin{array}{l}83,92 \pm \\
0,11^{\beta A e}\end{array}$ & $\begin{array}{c}85,02 \pm \\
0,17^{\beta \mathrm{Be}}\end{array}$ & $\begin{array}{l}34,15 \pm \\
0,13^{\beta \mathrm{Ae}}\end{array}$ & $\begin{array}{c}50,04 \pm \\
0,26^{\text {Be }}\end{array}$ \\
\hline
\end{tabular}

[P]: concentration of each product $(\% \mathrm{v} / \mathrm{v}), F 2$ : Yogurt + Soursop and blackberry pulps + Sweeteners, F3: Yogurt + Soursop and blackberry pulps + Sweeteners $+p H$ regulator, SP: soursop pulp, BP: blackberry pulp. Different Greek letters $(\alpha$ y $\beta)$ represent significant difference $p$-values between drinks (F2 and F3) and blackberry and soursop pulps (PM and PG). Different capital letters ( $A$ and $B$ ) in the same row indicate significant difference $p$-values between times by each product. Different lowercase letters $(a, b, c, d$ and $e)$ in the same column indicate significant differences ( $p$-values) between products concentration 100; 75; 50; 25; $12,5 ; 6,25 ; 3,15 \%)$. Experiments were made in triplicate \pm standard deviation. 
Studies by Hassimotto et al. reported a content of $120 \pm 8 \mathrm{mg}$ gallic acid equivalent (AGE) of total phenols per 100 grams of frozen soursop pulp [57]. Moreover, the authors Vijayameena et al. note that the acetogenins from Annonaceae family are also responsible for antioxidant power, related to the ability to inactivate reactive oxygen species such as singlet oxygen and peroxide radicals. They also attributed the high antioxidant properties of the soursop pulp to its high content of vitamin C [58]. The United States Department of Agriculture in 2010 described that soursop pulp provides a total of $20.60 \mathrm{mg} / 100 \mathrm{~g}$ of vitamin C.

Berries are generally rich in organic acids such as citric acid, malic acid, tartaric acid, and fumaric acid, some vitamins (ascorbic acid and folic acid), and phytochemicals such as phenolic compounds. Phenolic compounds belong to a broad and heterogeneous group of chemical compounds that have one or more aromatic rings and one or more hydroxyl groups; they tend to donate an electron or a hydrogen atom to a free radical making it a harmless molecule. Phenolic compounds occur in free and conjugated forms with sugars, acids, and other water-soluble biomolecules (phenolic acids, flavonoids, and quinones) or insoluble like tannins. Blackberries antioxidant power is attributed to its content of phenolic compounds including flavonoids such as anthocyanins (cyanidin glycosides and glycosides pelargonidin), flavonoids (quercetin, myricetin and kaempiferol), and flavonoids (catechin and epicatechin). In turn, phenolic acids (hydroxybenzoic acids and hydroxycinnamic acids) and hydrolysable tannins are ellagitannins like. These components, either individually or in combination, are primarily responsible for the health benefits of this berry, in addition to its antioxidant properties [34]. Studies by Rodriguez et al. in 2010 reported polyphenol content between 95 and $135 \mathrm{mg}$ equivalent gallic acid per 100 grams of blackberry (Rubus glaucus B.).

\section{CONCLUSION}

Blackberry pulp demonstrated the highest cytotoxic activity against tumor cells MCF-7, compared to soursop pulp and elaborated functional beverages. However, it was found that the cytotoxic activity of both formulations prepared (F2 and F3) as pulps were fairly good, being highly effective for the inactivation of breast tumor cells MCF-7 and prostate tumor cells PC3. Moreover, blackberry pulp and soursop pulp demonstrated a high antioxidant activity, with a synergistic effect accomplished for the mixture on F2 and F3. Therefore, the drinks have a favorable content on health claims. More advanced studies would help generate "in situ" fair evidence to confirm these promising benefits.

\section{DISCUSSION}

Exposing cells in a cell line to various combinations of fruit pulp and the formulated beverages are not equivalent to a clinical trial in which humans consume these beverages. Human digestion and absorption likely alter anti-cancer and antioxidant activity. While the findings in this area were interesting, they represent a very preliminary step in establishing the usefulness of these compounds in human health.

List of Abbreviations: HeLa, human cervix carcinoma cells; PC3, human prostate carcinoma cells; MCF-7, breast carcinoma without over-expression of the HER2/c-erb-2 gene; SKBr3, breast 
carcinoma in which the HER2/c-erb-2 gene is over-expressed, MTT (3- (4,5-dimethylthiazol-2yl)-2,5-diphenyl-2H-tetrazolium bromide); DMSO, dimethyl sulfoxide; DPPH, 1,1-diphenyl-2picrylhydrazyl (DPPH); SP, soursop pulp; BP, blackberry pulp; F2, formulation two of the functional beverage $\left(\mathrm{BP}+\mathrm{SP}+\right.$ Yogurt + Truvía ${ }^{\circledR}+$ Sacarose $) ; \mathrm{F} 3$, formulation tree of the functional beverage $\left(\mathrm{BP}+\mathrm{SP}+\right.$ Yogurt + Truvía ${ }^{\circledR}+$ Sacarose + Sodium tripolyphosphate $) ; \mathrm{pH}$ regulator, Sodium tripolyphosphate; $\mathrm{IC}_{50}$, half maximal inhibitory concentration; SI, the selectivity index as a result of $\mathrm{IC}_{50}$ control cells/ $/ \mathrm{IC}_{50}$ tumor cell line (derived from dividing the $\mathrm{IC}_{50}$ value in control cells between calculated for each tumor line with each product studied individually); cGMP, cyclic guanosine monophosphate; cAMP, cyclic adenosine monophosphate; ATP, adenosin triphosphate; AGE, gallic acid equivalent.

Authors' Contributions: RR, AZ, FA, and FS participated in research design. AZ, RR, and FS participated in the writing of the paper. AZ, RR, FA, and FS participated in the performance of the research; AZ, RR, FS, and FA participated in data analysis.

Competing Interests: There are no conflicts of interest to declare.

Acknowledgements and funding: All the research was self-financed. Special thanks to Universidad Central de Venezuela for their support and invaluable help to Prof. Alexis Zambrano, Prof. Adelaida Durán, Dr. Rosa Raybaudi-Massilia, Ph.D. Francisco Arvelo, B. Sc. Felipe Sojo, MSc. Raúl Martínez Valdivieso, and B. Sc. Fabiana Barrios.

\section{REFERENCES}

1. Roy A, Jauhari N, Bharadvaja N: Medicinal Plants as a Potential Source of Chemopreventive Agents. In Natural Products and Biotechnological Implements. Edited by Akhtar M., Swamy M. Singapore: Anticancer Plants: Springer; 2018, 2 (6): 109-139.

2. Balasubramanian K, Ragunathan R: Study of antioxidant and anticancer activity of natural sources. J. Nat. Prod. Plant Resour 2012, 2 (1): 192-197.

3. Dai J, Mumper RJ: Plant Phenolics: Extraction, Analysis and Their Antioxidant and Anticancer Properties. Molecules 2010, 15: 7313-7352.

4. Boivin D, Lamy S, Lord-Dufour S, Jackson J, Beaulieu E, Cote M, Moghrabi A, et al.: Antiproliferative and antioxidant activities of common vegetables: A comparative study. Food Chemistry 2009, 112: 374-380.

5. Monino M, Rodrigues E, Tapia MS, Domper A, Vio F, Curis A, et al.: Evaluación de las actividades de promoción de consumo de frutas y verduras en 8 paises miembros de la Alianza Global de Promoción al Consumo de Frutas y Hortalizas "5 al dia" - AIAM5. Rev Esp Nutr Hum Diet 2016, 20 (4): 281 - 297.

6. World Health Organization: Diet, nutrition and the prevention of chronic diseases. World Health Organ Tech Rep Ser 2003: 916.

7. Más fruta y hortalizas-Departamento de Agricultura y Protección del Consumidor [http://www.fao.org/ag/esp/revista/0606sp2.htm] 
8. The Healthy Eating Plate-Department of Nutrition, Harvard School of Public Health [https://www.hsph.harvard.edu/nutritionsource/healthy-eating-plate/]

9. Ozen AE, Pons A, Tur JA: Worldwide consumption of functional foods: a systematic review. Nutr Rev 70 2012: 472-81.

10. Corbo MA, Bevilacqua A, Petruzzi L, Casanova FP, Sinigaglia M: Functional Beverages: The Emerging Side of Functional Foods Commercial Trends, Research, and Health Implications. Comprehensive Reviews in Food Science and Food Safety 2014, 13: 1192 1206.

11. Siro I, Kapolna E, Kapolna B, Lugasi A: Functional food. Product development, marketing and consumer acceptance-A review. Appetite 2008, 51: 456-467.

12. Granato D, Branco GF, Nazzaro F, Cruz AG, Faria JAF: Functional foods and non-dairy probiotic food development: trends, concepts, and products. Compr Rev Food Sci Food Saf 2010, 9: 292-302.

13. Burdock GA, Carabin IG, Griffiths JC: The importance of GRAS to the functional food and nutraceutical industries. Toxicology 2006, 221: 17-27.

14. Kwak NS, Jukes DJ: Functional foods. Part 1 . The development of a regulatory concept. Food Control 2001, 12: 99-107.

15. Menrad K: Market and marketing of functional food in Europe. Journal of Food Engineering 2003, 56: 181-188.

16. Roberfroid MB: An European consensus of scientific concepts of functional foods. Nutrition 2000, 16: 689-691.

17. Martirosyan DM, Singh J: A new definition of functional food by FFC: what makes a new definition unique? Functional Foods in Health and Disease 2015, 5 (6):209-223.

18. Correia R, Borges KC, Medeiros MF, Genovese MI: Bioactive compounds and phenoliclinked functionality of powdered tropical fruit residues. Food Science and Technology International 2012, 18 (6): 539-547.

19. Miller ER III, Appel LJ, Risby TH: Effect of dietary patterns on measures of lipid peroxidation: Results from a randomized clinical trial. Circulation 1998, 98: 2390 - 2395.

20. Cirico TL, Omaye ST: Additive or synergetic effects of phenolic compounds on human lowdensity lipoprotein oxidation, Food Chem. Toxicol 2006, 44: 510 - 516

21. Zafra-Stone S, Yasmin T, Bagchi M., Chatterjee A, Vinson J, Bagchi D: Berry anthocyanins as novel antioxidants in human health and disease prevention. Mol Nutr Food Res 2007, 51: $675-683$.

22. Hatfield, G: Encyclopedia of Folk Medicine: Old World and New World Traditions, 1st ed. ABC-CLIO 2004: 392.

23. Castro D, Teodoro A: Anticancer properties of bioactive compounds of berry fruits - A review. Br J Med Med Res 2015, 6(8): 771-794.

24. Juranic Z, Zizak Z: Biological activities of berries: From antioxidant capacity to anti-cancer effects. Biofactors 2015, 23(4): 207-211. 
25. Feresin RG, Zhang J, Elam M, Hooshmand S, Kim J, Arjmandi, BJ: Effects of blackberry and blueberry polyphenol extracts on NO, TNF- $\alpha$, and COX-2 production in LPS-stimulated RAW264.7 macrophages. Faseb J 2012, 26: 823.20.

26. Marquina MA, Corao GM, Araujo L, Buitrago D, Sosa M: Hyaluronidase inhibitory activity from the polyphenols in the fruit of blackberry (Rubus fruticosus B.) Fitoterapia 2002, 73: $727-729$.

27. Tavares L, Figueira I, McDougall GJ, Vieira HL, Stewart D, Alves PM, Santos CN: Neuroprotective effects of digested polyphenols from wild blackberry species. Eur J Nutr 2013, 52: 225-236.

28. Dai J, Patel JD, Mumper RJ: Characterization of blackberry extract and its antiproliferative and anti-inflammatory properties. J Med Food 2007, 10: 258-265.

29. Kalt W, Forney C, Martin A, Prior RL: Antioxidant Capacity, Vitamin C, Phenolics, and Anthocyanins after Fresh Storage of Small Fruits. J Agric Food Chem 1999, 47: 4638-4644.

30. Benvenuti S, Pellati F, Melegari M, Bertelli D: Polyphenols, anthocyanins, ascorbic acid, and radical scavenging activity of Rubus, Ribes, and Aronia. J Food Sci 2004, 69: 164-169.

31. Wang WD, Xu SY: Degradation kinetics of anthocyanins in blackberry juice and concentrate. J Food Eng, 82: 271-275

32. Guerrero J, Ciampi L, Castilla A, Medel F, Schalchli H: Capacidad antioxidante, antocianinas, y fenoles totales de bayas silvestres y cultivas en chile. Chilean Journal of agriculture research 2010, 70(4): 537-544.

33. Johnson MH, de Mejia EG: Comparison of chemical composition and antioxidant capacity of commercially available blueberry and blackberry wines in Illinois. J Food Sci 2012, 77: 141-148.

34. Skrovankova S, Sumczynski D, Mlcek J, Jurikova T, Sochor J: Bioactive Compounds and Antioxidant Activity in Different Types of Berries. Int J Mol Sci 2015, 16: 24673-24706.

35. Kong JM, Chia LS, Goh NK, Chia TF, Brouillard R: Analysis and biological activities of anthocyanins, Phytochemistry 2003, 64: 923-933.

36. Prior RL: Fruits and vegetables in the prevention of cellular oxidative damage. Am J Clin Nutr 2003, 78: 570S-578S.

37. Heber D: Vegetables, fruits and phytoestrogens in the prevention of diseases. J Postgrad Med 2004, 50: 145 - 149.

38. Juranic Z, Zizak Z: Biological activities of berries: From antioxidant capacity to anti-cancer effects. Biofactors 2005, 23: 207-211.

39. Duthie GG, Gardner PT, Kyle JA: Plant polyphenols: Are they the new magic bullet? Proc Nutr Soc 2003, 62: 599-603.

40. Narayan MS, Naidu KA, Ravishankar GA, Srinivas L, Venkataraman LV: Antioxidant effect of anthocyanin on enzymatic and non-enzymatic lipid peroxidation, Prostaglandins Leukot Essent Fatty Acids 1999, 60: 1-4. 
41. Franco E: Actividad antioxidante in vitro de las bebidas de frutas. Bebidas -Alda Editores Tecnicos, Junio/Julio 2006, 20-27.

42. Lim TK: Annona muricata. Edible Medicinal and Non-Medicinal Plants: Volume 1, Fruits 212, 190-200.

43. Raybaudi-Massilia R, Suárez A, Arvelo F, Sojo F, Mosqueda-Melgar J, Zambrano A, Calderon-Gabaldon MI: An Analysis In-vitro of the Cytotoxic, Antioxidant and Antimicrobial Activity of Aqueous and Alcoholic Extracts of Annona muricata L. Seed and Pulp. British Journal of Applied Science and Technology 2015, 5(4): 333-341.

44. Bigliardi B, Galati F: Innovation trends in the food industry: The case of functional foods. Trends in Food Science and Technology 2013, 31 (2): 118-129.

45. Mosmann T: Rapid colorimetric assay for cellular growth and survival: application to proliferation and cytotoxicity assay. J Inmunol Meth 1983, 65: 55-63.

46. Callacondo-Riva D, Quispe-Mauricio A, Lindo-Gamarra S, Vaisberg AJ: Cytotoxic activity of ethanol extracts of Gnaphalium spicatum "Keto Keto" in cultured human tumor cell lines. Rev Peru Med Exp Public Health 2008, 25: 380-5.

47. Celep E, Aydin A, Yesilada A: A comparative study on the In-vitro antioxidant potentials of three edible fruits: Cornelian cherry, Japanese persimmon and cherry laurel. Food Chem Toxicol 2012, 50: 3329-3335.

48. Muñoz A, Sojo F, Merchan D, Kouznetsovc V, Arvelo F: Cytotoxic effects of new trans2,4-diaryl-r-3-methyl-1,2,3,4-tetrahydroquinolines and their interaction with antitumoral drugs gemcitabine and paclitaxel on cellular lines of human breast cancer. ChemicoBiological Interactions 2011, 189: 215-221.

49. Gajalakshmi S, Vijayalakshmi S, Rajeswari V: Phytochemical and pharmacological properties of Annona muricata: A review. Int J Pharm Pharmaceu Sci 2012, 4 (2): 3-6.

50. Jyothi A, Venkatesh K, Chakrapani P, Roja R: Phytochemical and pharmacological potential of Annona cherimola - A review. Int J Phytomed 2011, 3: 439-447.

51. Padmaa P, Chansouria J, Khosa R: Wound Healing Activity of Annona muricata extract. J Pharm Res 2009, 2(3): 404-406.

52. Morre D, de Cabo R., Farley C, Oberlies N, McLaughlin J: Mode of action of bullatacin, a potent antitumor acetogenin: Inhibition of NADH oxidase activity of HeLa and HL-60, but not liver, plasma membranes. Life Sci 1995, 56: 343-348.

53. Kojima N, Tanaka T: Medicinal Chemistry of Annonaceous Acetogenins: Design, Synthesis, and Biological Evaluation of Novel Analogues. Molecules 2009,14: 3621-3661.

54. Chiu H, Chih T, Hsian Y, Tseng C, Wu M, Wu Y: Bullatacin, a potent antitumor Annonaceous actogenin, induces apoptosis through a reduction of intracellular cAMP and cGMP levels in human hepatoma 2.2.15 cells. Biochem Pharmacol 2003, 65 (3): 319-327.

55. Bowen-Forbesa C, Zhangc Y, Nair M: Anthocyanin content, antioxidant, anti-inflammatory and anticancer properties of blackberry and raspberry fruits. Journal of Food Composition 

and Analysis 2010, 23 (6): 554-560.

56. Ross H, McDougall G, Stewart D: Antiproliferative activity is predominantly associated with ellagitannins in raspberry extracts. Phytochemistry 2007, 68: 218-28.

57. Vit P, Santiago B, Perez-Perez E: Composición química y actividad antioxidante de pulpa, hoja y semilla de guanábana Annona muricata L. Interciencia 2014, 39 (5): 350-353.

58. Hassimotto I, Genovese M, Lajolo F: Antioxidant Activity of Dietary Fruits, Vegetables, and Commercial Frozen Fruit Pulps. J Agric Food Chem 2005, 53 (8): 2928-2935.

59. Vijayameena C, Subhashini G, Loganayagi M, Rames B: Phytochemical screening and assessment of antibacterial activity for the bioactive compounds in Annona muricata. Int $\mathrm{J}$ Curr Microbiol Appl Sci 2013, 2(1): 1-8.

60. Rodríguez L, Lopez L, Garcia M: Determinacion de la composición química y actividad antioxidante en distintos estados de madurez de frutas de consumo habitual en Colombia, mora (Rubus glaucus B.), maracuyá (Passiflora edulis S.), guayaba (Psidium guajava L.) y papayuela (Carica cundinam). Alimentos Hoy. Asociacion Colombiana de Ciencia y Tecnología de Alimentos 2010, 19 (21): 1-9. 